\title{
Strategic Leadership Planning for School Improvement: A Successful Model from the Kingdom of Bahrain
}

\author{
Masooma Al Mutawah \\ Bahrain Teachers College - University of Bahrain \\ malmutawah@uob.edu.bh
}

\begin{abstract}
This chapter will cover basic theories and practices of successful leadership through strategic planning. A range of issues will be explored for school improvement in an educational setting, such as: Managing educational change by identifying individual and organizational drivers for improvement; Accountability and evaluation across international contexts with consideration for how it might work in a range of situations in the national context; Preparation to lead and assess teaching and learning; How to build cohesive diversity cultures in schools that promote a positive environment where the differences will be accepted; Examining processes that promote change for improvement; The primary responsibilities of school leaders as change agents within their organizations; How to ensure sustainability of educational reforms to improve school effectiveness with a focus on the role of school leaders in the process.
\end{abstract}

Keywords: Strategic leadership, Successful leadership, Cultural context.

\section{Introduction}

Many literatures have not agreed to one unique definition for leadership. Hundreds of definitions were shown in literature of what it should take to have leaders. However, Bush (2003) stated in his book about school leadership that: "A central element in many definitions of leadership is that there is a process of influence" (Bush, 2003: 4). Moreover, when we as educators discuss strategic leadership, we obviously talk about leaders, not managers. Even though the difference might not be clear for many people 
This is a limited preview of the chapter.

To read the full-text chapter, get access by purchasing this chapter or consider buying the complete book. If your library has subscription to EBSCOhost, the chapter including other chapters of the book can be accessed through your library.

This chapter is a part of the book, 'Innovations in Educational Leadership and Continuous Teachers' Professional Development' ISBN (paperback): 978-8I-948483-2-5; ISBN (ebook): 978-8I' $948483-3-2$

Book DOI: https://dx.doi.org/ro.46679/isbn9788194848325 Chapter DOI: https://dx.doi.org/I0.46679/isbn978819484832505 
by providing the professional development programmes they need. Furthermore, by following the instructional leadership model, school leaders should build a culture of teamwork, sharing responsibilities anda constructive collaborative vision that all school staff feel they are part of. That will help to overcome any transformational leadership challenges. Furthermore, looking carefully into diversity constraints and challenges to overcome them is very important, as well as the cultural context differences, since what can work extremely well in one context might fail in another. Finally, school leadership should play a significant sufficient role in education policy and reform because of the globalization and labour skills needs that force the curriculum change.

\section{References}

Bahrain Ministry of education. Special Education Guide. Special Education Directorate. Available at http://www.moe.gov.bh/pdf/disabled-book.pdf (accessed $8^{\text {th }}$ May 2020).

Bahrain Teachers College. Available at http://www.btc.uob.edu.bh/about-btc(accessed $4^{\text {th }}$ May 2020).

Bhebhe, S., Nyathi, W. \& Bhebhe, S. (2019). The organisational structure and teachers' performance in high schools: Perceptions from head teachers and teachers. International open Journal of Educational Research. 2(5). I-I2.

Bolman, L. G. E Deal, T. E. (20I7). Reframing Organizations. The Structural Frame. Jossey, Bass. 43-93.

Burns, M. K., Preast, J. L., Kilpatrick, K. D., Taylor, C. N., Young, H., Aguilar, L., Allen, A., Copeland, C., Haider, A E Henry, L. (20I7). Leadership Theory for School Psychologists: Leading for Systems Change. Communiqué Professional Practice. 46(2), 30-3I.

Bush, T. EJ Glover, D. (2003). School Leadership: Concepts and Evidence. National College for School Leadership. 42.

Center for the Future of Teaching and Learning (20II). School Leadership: A Key to Teaching Quality. SRI International. Available at https://files.eric.ed.gov/fulltext/ED515279.pdf (accessed I5 ${ }^{\text {th }}$ May 2020)

Díez, F., Villa, A., López, A.L. \& Iraurgi, I. (2020). Impact of quality management systems in the performance of educational centers: educational policies and management processes. Heliyon, 6(4), art. no. e03824.

Douglas, B. R. (2007). Leading to Change / Making Strategic Planning Work. Educational leadership65(4), 86-87. 
Dupriez, V. EDDumay, X. (2006). Inequalities in school systems: effect of school structure or of society structure?. Comparative Education.42(2). 243260.https://doi.org/10.1080/03050060600628074

Education and Training Quality Authority. Schools Reviews Handbook. Available at https://www.bqa.gov.bh/En/Publications/DocLib/EN\%20V6.pdf(accessed io ${ }^{\text {th }}$ May 2020).

Education and Training Quality Authority. Vision, Missions \&? Values. Available athttps://www.bqa.gov.bh/Ar/Pages/Home.aspx (accessed $8{ }^{\text {th }}$ May 2020).

ECRA.(2015).Creating the Future: Strategic Planning for Schools. Available at https://ecragroup.com/wp-content/uploads/dlm_uploads/20I6/07/StrategicPlanning-White-Paper.pdf (accessed I9 ${ }^{\text {th }}$ April 2020).

Goh, J. W. P., Hairon, S. Eं Lim, S. Q. W. (2019). Understanding Distributed Leadership Practices in the Cultural Context of Singapore Schools (Ed.). Perspectives on School Leadership in Asia Pacific Contexts. Springer. II-zo. https://doi.org/10.1007/978-981-32-9160-7

Halladay, D. (2019, December 9).School Strategic Planning - How to Ensure Success. Private School Review. Available at https://www.privateschoolreview.com/blog/school, strategic-planning-how-to-ensure-success(accessed 9 th May 2020).

Harris, A. (2004). Distributed Leadership and School Improvement: Leading or Misleading?.Educational Management Administration E' Leadership. 32 (I), II-24. DOI: IO.II77/I74II43204039297

Heck, R. H. छ Hallinger, P. (20I4). Modeling the longitudinal effects of school leadership on teaching and learning. Journal of Educational Administration, 52(5), 653681.https://doi.org/10.II08/JEA-08-2013-0097

Holmes,W. T.छScull W. R. (20I9).Reframing organizations through leadership communications: the four-frames of leadership viewed through motivating language. Development and Learning in Organizations. Emerald Publishing Limited. https://doi.org/Io.II08/DLO-09-2018-0107

Kabeta,M. K., Manchishi, P.C. \& Akakandelwa, A. (2015). Instructional Leadership and Its Effect on the Teaching and Learning Process: The Case of Head teachers in Selected Basic Schools in the Central Province of Zambia. International Journal of Science and Research. 4(4), 1876-1884.

Liang, J. G. EJ Wang, F. (20I9). Teacher Leadership? Voices of Backbone Teachers in China. Journal of School Leadership. 29(3). 229-247.DOI: Io.II77/1052684619836826

Manaze, M. (2019). Practice and Challenges of Distributed Leadership at Public Secondary Schools of Dessie City Administration. Asian Journal of Education and e-Learning. 入(4). 95'II2. 
Murphy, C. D. R. (20I8). Educational Leaders and Inclusive Special Education: Perceptions, Roles, and Responsibilities. Journal of Education and Culture Studies.2(4), 248-270. http://dx.doi.org/Io.22158/jecs.v2n4p248

Ni, Y., Hollingworth, L., Rorrer, A. छ Pounder, D. (20I6). The Evaluation of Educational Leadership Preparation Programs. The Evaluation of Programs. 285-307.

Nikolaros, J. (20I5). Strategies for Effective School Leadership. Global Journal of Educational Studies. I(I), 45-5I.

Pont, B. (20I4). School leadership: From Practice to Policy. Journal of Educational Leadership and Management. 2(I), 4-28. http://dx.doi.org/10.447/ijelm.2014.07

Pont, B., Nusche, D. छ Moorman, H. (2008).Improving School Leadership: Volumer: Policy and Practice. OECD. I-I99.

Ready, D., Lee, V. छ̋ Welner, K. G. (2004). Educational Equity and School Structure: School Size, Overcrowding, and Schools-Within Schools. Teachers College Record. IO6 (10). 1989-2014.

Seashore, k. R. (2009). Leadership and change in schools: personal reflections over the last 30 years. J Educ Change. I0, I29-I40. DOI 10.1007/sio833-009-9III-4

Senol, H. (20I9).Professional Development of Educational Leaders. Educational Leadership. IntechOpen. http://dx.doi.org/I0.5772/intechopen.89260

Sharma, M. K. E Jain. S.(2013).Leadership Management: Principles, Models and Theories. Global Journal of Management and Business Studies. 3(3), 309-318.

Smith, S. B. (2016). The Role of Leadership Style in Creating a Great School. SELU Research Review Journal, I(I), 65-78.

Tahir, L. M., Musah, M. B., Al-Hudawi, S. H. V. \& Daud, K. (2020). Becoming a Teacher Leader: Exploring Malaysian In-Service Teachers' Perceptions, Readiness and Challenges. Education and Science. 45(202), 283-310. DOI: 10.15390/EB.2020.7362.

Townsend, T. (20II). School leadership in the twenty-first century: different approaches to common problems?. School Leadership and Management, 3I(2), 93-103. DOI: I0.1080/13632434.20II.572419 